\title{
ARTICLE
}

\section{Fractures and Alliances: Labour Relations and Worker Experiences in Construction}

\section{Suzanne E. Mills}

CONSTRUCTION is important by virtue of its prevalence in Canada; it is one of the most common types of employment held by men, ${ }^{1}$ employing approximately 1.4 million people. ${ }^{2}$ Its ubiquity, in addition to its connection to growth in other sectors, has meant that the construction sector is closely followed by governments, who often view construction employment as both an indicator of growth and a source of economic stimulus. ${ }^{3}$ Despite this, however, labour scholars have paid less attention to construction than to other sectors of employment. Though there is a sizable literature on health and safety and on gender in the construction trades, research about contemporary labour relations is notably sparse. Undeniably, conducting research on construction workers and unions is challenging. The mobile and fragmented character of the construction industry makes recruiting interview participants difficult, and labour unions are often secretive and reluctant to share information with researchers. Unions in the sector also have a mixed history, on the one hand giving voice to workers' concerns and providing for worker protection, while on the other hand supporting right-leaning governments, promoting business

1. In 2016, the construction sector employed 7.7 per cent of the total labour force and 12.9 per cent of the male labour force in Canada. Statistics Canada, “Table 282-0007: Labour Force Survey Estimates (LFS), by North American Industry Classification System (NAICS), Sex and Age Group, Unadjusted for Seasonality," CANSim (database), accessed 6 January 2017.

2. Statistics Canada, "Table 282-0094: Labour Force Survey Estimates (lfs), by North American Industry Classification System (naics), Canada, Seasonally Adjusted," CAnsim (database), accessed 25 January 2017.

3. Natural Research Council Canada, "Construction," NRC website, accessed 25 January 2017, http://www.nrc-cnrc.gc.ca/eng/rd/construction/index.html. 
unionism and creating divisions between unionized and non-unionized workers and skilled and unskilled workers. Understanding the complexity of the industry, both its organized and its unorganized elements, is thus a demanding research endeavour.

The paucity of research about the sector, however, has also led governments and scholars to homogenize the tremendous diversity within the industry. Construction employment is often portrayed as offering uniform, well-paying jobs, though there is a striking contrast between the working conditions of unionized skilled workers and those of unskilled migrants working informally. Workers must also navigate geographically distinct labour markets. Whereas the scale of the labour market for construction work in urban areas allows for continuous work opportunities within a commutable area, the labour market in less populated regions often spans a much larger area, requiring workers to travel long distances to maintain employment. Worker representation in the sector is equally diverse, ranging from non-union workers to company unions to building and construction trades unions (вСтUs). Even characterizations of встUs are often misleading, since locals and unions can differ markedly in their approach to worker representation, organizing, and the inclusion of women and/or racialized workers. Finally, the sector is also one in which large numbers of recent immigrants, Indigenous people, and racialized men find work, albeit often following rigid racial hierarchies. Perhaps the only constant is the extreme underrepresentation of women in most construction occupations, despite decades of employment programs designed to foster their integration. This special section of Labour/Le Travail aims to make a small contribution to mapping the complex and unique labour relations in construction work in Canada.

To set the stage for the articles that follow, this introduction outlines some of the distinct attributes of the construction industry, as well as some of the ways that construction employment has become increasingly complex. Several intrinsic features of construction, in conjunction with over a century of industry change and labour relations, have led to a diverse array of employment relationships, forms of worker representation, and worker experiences. In particular, the fragmented nature of construction work in terms of both time duration and location - or temporality and spaciality - has influenced union strategies in ways that have inevitably fostered their decline. Further, declining unionization has occurred alongside increasing diversity in the sector, although it is a diversity that adheres to racial and gendered occupational hierarchies. How these attributes, along with the continuous growth in construction employment, have made construction projects attractive to states - both as an element of economic development strategies and as a way to foster training and employment for groups historically excluded from construction or the skilled trades - figures prominently in any discussion of contemporary relations in the construction sector. I finish by introducing how each of the articles that follow provides greater insight into issues facing 
construction workers in the current Canadian context. Together, these articles demonstrate that construction work is central to an understanding of contemporary changes in work and worker representation in Canada and therefore necessitates greater attention from labour scholars.

\section{Spatial and Temporal Fragmentation and Declining Union Density}

THOUgH MANY WORKPLACES are precarious, those in construction are intrinsically so. Construction work is spatially and temporally fragmented, as both the location and the duration of work is in flux. Several authors have drawn connections between characteristics of the industry and worker precarity. ${ }^{4}$ Ivana Fellini, in particular, discusses how worker precarity stems from the nature of the labour process and the products of labour. Because the product of work is spatially fixed and temporally finite, workers need to travel from site to site to continue working after a project is completed. Moreover, the number and types of workers required at a work site at any given time is constantly changing because the production process itself is fragmented, with different contractors doing different portions of the work on varying time schedules. Though Fellini does not mention regional fluctuations, those working in the industry in Canada's hinterland are quick to point out that fluctuation in the numbers of differently skilled workers is amplified by regional growth cycles. As well, because the demand for construction workers closely follows the business cycles of other sectors, labour demand is prone to oscillation, reaching deeper troughs and higher peaks than other forms of employment. The demand for workers is therefore in continuous flux, both spatially and temporally. The result is that the industry ultimately depends on the existence of a flexible pool of readily available workers of diverse skill levels. "Skills shortages" are a persistent issue, since there can never be too large a pool of employable construction workers, even in difficult economic times.

This inherent contingency is made further pronounced by a process of uneven development, in which new investment flows both into and out of different geographic areas, thus causing labour shortages during development spikes and unemployment during downturns. In large urban centres, cycles of investment and disinvestment can occur within the confines of the metropolitan area, providing continuous work within daily-commuting distance. In northern and rural regions, however, the transient nature of construction work and spatial fluctuations in labour are stretched over a larger area. Entire regions often see huge spikes in employment as investment flows into and out of the area, most commonly resulting from resource development. Resource development projects often require more construction workers than

4. Edmund Heery, "Trade Unions and Contingent Labour: Scale and Method," Cambridge Journal of Regions, Economy and Society 2, 3 (2009): 429-442; Ivana Fellini, Anna Ferro \& Giovanna Fullin, "Recruitment Processes and Labour Mobility: The Construction Industry in Europe,” Work, Employment and Society 21, 2 (2007): 277-298. 
are available in local labour markets; however, when resource capital leaves a region, the amount of work in the area declines precipitously. The smaller economies of rural areas and small urban centres are often dwarfed by the construction needs of large industrial projects. Employers therefore rely heavily on worker mobility to meet their labour needs.

These fluctuations in labour demand over time and space have injected a level of precarity into construction work. Even those employed in standard employment relationships move from job site to job site, and as a result, work conditions change frequently. And yet, precarity can be intensified or mitigated depending on the employment relationship. In particular, many contingent employment relationships that are common in construction transfer the financial risks of discontinuous work to individual workers, resulting in work that is unstable or insecure. According to Edmund Heery, some of the most common types of contingent employer relationships in the sector include short-term contracts, in which workers are laid off after the completion of a job (most common in the industrial and institutional sectors); self-employment or misclassified self-employment (common in the residential sector); and agency models, in which union or non-union hiring halls facilitate the movement of workers from job to job. ${ }^{5}$ The precarity resulting from a lack of permanence or security of employment is accentuated by spatial instability; workers do not know where they will be working next. Maintaining mobility - among work sites and in some cases over large geographic areas - is often necessary to ensuring year-round employment. In underdeveloped regions, this link between geographical mobility and employment security is heightened, and prospective apprentices are frequently told that they must be willing to travel if they want to stay in the trade.

In this context, ВСтUs play an important role in facilitating worker mobility. ВСтUs mitigate employment insecurity resulting from fluctuating labour markets by facilitating the movement of workers from job to job, through their hiring hall system. Through an ever-changing dance of mobility, exclusion, and organizing, ВС TUs strive to keep their unemployment lists low. ВСтU business managers and agents also safeguard their members against long periods of unemployment when construction slows locally, by facilitating the movement of their members to other jurisdictions through travel cards. Although the job security provided by вСтUs is critical to lessening the temporal and spatial precarity faced by construction workers, it also fosters "job control unionism" tendencies, which are exclusionary and, as will be discussed below, have contributed to the decline of union density over the long term in the United States. ${ }^{6}$ A lack of continuous work, however, is only one aspect of worker insecurity. Scholars of precarious work note that lack of control over the labour

5. Heery, "Trade Unions."

6. Heery, "Trade Unions"; Mark Erlich \& Jeff Grabelsky, "Standing at a Crossroads: The Building Trades in the Twenty-First Century," Labor History 46, 4 (2005): 421-445. 
process, reduced regulatory protection, and low income also contribute to feelings of instability among workers. ${ }^{7}$ When the system of industrial relations in construction was such that almost all workers were represented by ВСT Us, workers were protected against each of these aspects of worker insecurity. ${ }^{8}$ Unions were able to protect workers because they had strong bargaining power, derived from their control over the supply of skilled labour within a geographical area, which they were able to harness to provide their members with high wages, union dispute resolution, access to benefits and pensions, and opportunities for continuous training through joint union-employerfunded apprenticeship and training programs.

Although numbers precisely documenting the per cent decline in construction union density are not readily available, most experts report losses in market share from the 1970 s through to the $2000 \mathrm{~s} .{ }^{9}$ Union protection is no longer the norm in construction: approximately 70 per cent of construction workers in Canada are not represented by a recognized bargaining agent. ${ }^{10} \mathrm{Of}$ those who are unionized, a growing number are represented by the Christian Labour Association of Canada (CLAC), a union that, as discussed by Steven Tufts and Mark Thomas below, collaborates with employers to undermine both collective representation and the strength of вСтUs. Non-unionized workers have less regulatory protection and little to no access to benefits and pensions. Although several factors contributed to the deterioration of the industrial relations system in Canada and the United States, there is consensus among scholars and practitioners that "job control" union strategies by BCTUs played a key role. ${ }^{11}$ Exclusive membership rules and an emphasis on servicing rather than organizing, although critical to lessening the precarity faced by their members, came at the expense of expanding union ranks. As described by David Weil,

In brief, trade unions operated with a "country club" mentality, leading them to focus on existing members while excluding a large - and growing - set of non-union workers who

7. Gerry Rodgers \& Janine Rodgers, eds., Precarious Jobs in Labour Market Regulation: The Growth of Atypical Employment in Western Europe (Geneva: International Institute for Labour Studies, 1989); Leah Vosko, Nancy Zukewich \& Cynthia Cranford, "Precarious Jobs: A New Typology of Employment," Perspectives on Labour and Income 4, 10 (2003): 16-26.

8. David Weil, "The Contemporary Industrial Relations System in Construction: Analysis, Observations, and Speculations," Labor History 46, 4 (2005): 447-471.

9. Joseph B. Rose, "Reforming the Structure of Collective Bargaining: Lessons from the Construction Industry," Canadian Labour and Employment Law Journal 17, 2 (2013): 403-411.

10. Union density in construction in Canada has hovered at approximately 30 per cent. Diane Galarneau and Thao Sohn, "Long-Term Trends in Unionization," Insights on Canadian Society, Statistics Canada - Catalogue No. 75-006-X (Ottawa: Minister of Industry, November 2013).

11. Weil, "Contemporary Industrial Relations System"; Erlich \& Grabelsky, "Standing at a Crossroads." 
were trained in union sector apprentice systems but were prevented from attaining full membership rights - and access to jobs - in that sector. ${ }^{12}$

According to Mark Erlich and Jeff Grabelsky, as the demand for construction workers expanded through the 1960s, 1970s, and 1980s, barriers to entering the вСтUs prevented a parallel expansion in union membership. ${ }^{13}$ "Job control" union strategies, exercised in consort with pro-employer regulatory changes and structural changes in the industry, set the stage for the expansion of non-unionized employers and the rise of "wall-to-wall" unions. ${ }^{14}$ According to Mike Rabourn, when faced with expanding demand for workers, BCTUs let the less profitable but more difficult to organize residential sector slip away. ${ }^{15}$ In Canada, regulatory changes that centralized bargaining structures and allowed double breasting by union contractors were introduced in each province through the 1960s and 1970s, and again through the 1980s and 1990s, in order to "balance the labour relations environment, by providing greater advantage to non-union contractors." ${ }^{6}$ The fragmented character of the sector and the prevalence of small firms created few barriers to entry, and non-union firms were quickly able to capitalize on these changes.

\section{Diversity, Differentiation, and Skill}

TOGETHER WITH INDUSTRY changes and shifting regulatory environments, the loss of market share among вСтUs has contributed to a polarization of working conditions, accentuating preexisting sectoral differences. The residential sector has long fostered small firms and self-employment and been susceptible to informal work arrangements, while the more regulated industrial and institutional sectors are more heavily unionized and generally offer greater worker protections and higher wages. ${ }^{17}$ However, declining BCTU density, particularly in residential and commercial sectors, has sped the rise of non-unionized contractors, accommodationist unions such as CLAC, and the use of migrant workers, as shown by Tufts and Thomas and by Jason Foster and Bob Barnetson in this section, among others. ${ }^{18}$ For example, from 2006 to 2011 in Toronto, self-employment in construction rose much more quickly than regular employment, and most of those self-employed

12. Weil, “Contemporary Industrial Relations System,” 448.

13. Erlich \& Grabelsky, "Standing at a Crossroads."

14. Wall-to-wall unions organize employees working in all trades together under one union, in contrast to the craft-organizing model employed by ВСтUs, which organizes workers by trade.

15. Mike Rabourn, “Organized Labor in Residential Construction,” Labour Studies Journal 33, 1 (2008): 9-26.

16. Rose, "Reforming the Structure."

17. Rabourn, "Organized Labor."

18. Erlich \& Grabelsky, "Standing at a Crossroads." 
were unincorporated firms with no employees. ${ }^{19}$ Changes to the Temporary Foreign Worker Program (TFW P) during the early 2000s facilitated the use of low-skill migrant workers in construction, leading to large influxes, particularly in Alberta, as outlined in the article by Foster and Barnetson. As a result, there now exists tremendous diversity among working conditions in construction. These can be charted along a continuum of precarity, with workers in unionized, highly skilled trades being able to garner high wages, benefits, and control over the labour process, at one end, and workers employed informally, by small contractors or as self-employed independent contractors, having greater employment insecurity, lower wages, and less control over the labour process, at the other end. Despite the significance of these developments, the literature continues to be skewed toward more stable unionized workers, as fewer scholars have explored the burgeoning non-union and informal construction sectors. ${ }^{20}$

The diversity of employment relationships can be observed in the unevenness of regulatory protection. As alluded to above, however, this unevenness also follows racial and ethnic hierarchies. ${ }^{21}$ White men who are Canadian citizens are more likely to work as full-time employees in highly unionized industrial or institutional sectors and to have stronger regulatory protection than women, racialized men, and noncitizens. The TFWP in particular has been criticized for failing to properly protect migrant workers from health and safety violations. Some high-profile health and safety violations, including one that resulted in the deaths of two Chinese temporary foreign workers in the tar sands, have drawn the attention of the media and public and highlighted the lack of regulatory oversight. ${ }^{22}$ Similar unevenness exists with respect to control over the labour process. Although highly skilled tradespersons often pride themselves on their control over the quality of their work and their role in the labour process, labourers as well as those in the civil trades - trades that are not regulated and have shorter apprenticeships - have much less control on the job site. ${ }^{23}$ Wages in construction also vary tremendously by

19. Although many tradesworkers work independently, small firms also regularly misclassify workers as self-employed to avoid commitments such as benefits and to reduce their health and safety liability. Konstantin Kilibarda, Constructing Toronto (Toronto: Toronto Workforce Innovation Group, 2015), 19.

20. Rebecca Torres, Rich Heyman, Solange Munoz, Lauren Apgar, Emily Timm, Cristina Tzintzun, Charles R. Hale, John McKiernan-Gonzalez, Shannon Speed \& Eric Tang, "Building Austin, Building Justice: Immigrant Construction Workers, Precarious Labor Regimes and Social Citizenship," Geoforum 45 (2013): 145-155.

21. For example, in Toronto, visible minorities and Indigenous people are overrepresented in lower-skilled trades and as labourers. Kilibarda, Constructing Toronto, 54.

22. Carol Christian, "53 Charges for CNRL, Contractors," Fort McMurray Today, 2 April 2009.

23. The decline in вст Us erodes training and apprenticeship ladders, given that non-union contractors or wall-to-wall unions such as CLAC practice dilution. The trend of using prefabricated products in construction has contributed to this dilution, because it encourages 
sector, skill level, and unionization. Although the wages of some construction workers hover just above minimum wage, highly skilled tradespersons, particularly those working on industrial projects and those who are collectively organized, garner considerably higher wages. Unions play a large role in the high wages earned by some construction workers. In 1999, the construction sector had the largest union wage premium of all industries in Canada, at 19 per cent. ${ }^{24}$ Unionized employment and work in more highly skilled trades, however, is not equally available to all workers. Indigenous people, racialized immigrants, and women are often overrepresented in low-skilled job classifications, such as civil trades, and as labourers or independent contractors, and few unions encourage women to become members. ${ }^{25}$

Trade unions have contributed to labour market segmentation in the sector, restricting access to the trades and highly skilled positions and often reinforcing divisions among workers on the basis of skill, ethnicity, immigration status, and sex. ${ }^{26}$ The exclusion of women and racialized men from BCTUs has flowed partially from the craft model of organizing, in which members are recognized as "skilled" workers - as opposed to nonmembers, who are "unskilled" or "less skilled" - in order to maintain union power. Within a misogynist and racist trades culture, the exclusion of unskilled workers translates into the exclusion of women and racialized men, who are deemed as unskilled or less skilled by virtue of their sex, skin colour, citizenship status, and/or language use. ${ }^{27}$ Because вС тUs gain some of their power (though not

the use of less-skilled workers to do jobs formerly done by skilled journeypersons. This has been particularly pronounced in civil trades that are less regulated such as carpenters or sheet metal workers.

24. Tony Fang \& Anil Verma, "Union Wage Premium," Perspectives on Labour and Income 3, 9 (2002): 13-19.

25. Although Aboriginal peoples are overrepresented in construction occupations in Canada, relative to non-Aboriginal people, and more likely to have trades certification than nonAboriginal people, a more refined analysis for Saskatchewan suggests the complexity of the situation. Aboriginal peoples are overrepresented in lower-paid occupations (e.g., cooks, carpenters, servers, roofers, bricklayers) and underrepresented in higher-skilled trades (e.g., plumbers, electricians). One exception is ironworkers; there is a long history of Iroquois men working in high steel. Moreover, among people with a trades certificate, the employment rate for Aboriginal peoples is 26 per cent lower than that of non-Aboriginal people. Sask Trends Monitor \& DC Strategic Management, A Review of the Gabriel Dumont Institute Aboriginal Employment Initiative (Saskatoon: Gabriel Dumont Institute, 2014); Jeannine Usalcas, "Aboriginal People and the Labour Market: Estimates from the Labour Force Survey, 2008-2010," Statistics Canada - Catalogue No. 71-588-X, no. 3 (Ottawa: Minister of Industry, November 2011); Suzanne Mills \& Anne St. Amand, "I Wanted a Career, Not a Job": First Nations and Métis Employment in the Construction of the Lower Mattagami River Project (Hamilton: Moose Cree First Nation, 2015), 86; Kilibarda, Constructing Toronto, 19.

26. Raymond Hudson, Producing Places (New York: Guilford, 2001).

27. Kris Paap, Working Construction: Why White Working-Class Men Put Themselves - and the Labour Movement - in Harm's Way (Ithaca: Cornell University Press, 2006); Robert H. Zieger, 
all) through differentiation, they invest heavily in both the demand for and their supply of highly skilled workers. For example, встUs often lobby governments to increase formal skill designations and certifications, to invest in training centres, and to create more stringent building codes. The quality of work on the job site is also maintained through self-monitoring and through fighting dilution (the downgrading of worker skill by hiring lower-skilled workers for a job). This heightened attention to skill has resulted in a culture in which workers try to differentiate themselves from one another along hierarchies of skill and by being a "good worker."

Research about gender and construction has revealed how this culture of skilled productivity has become embedded in white working-class masculinity. ${ }^{28}$ Building on David Roediger's contention that whiteness is a form of wage, Kris Paap has argued that the physicality of the work itself acts in consort with depictions of masculinity to provide male workers with both a "physiological and psychological wage" that incurs both internal and external benefits. ${ }^{29}$ Male workers thus gain status by reinforcing heteronormative masculinity through the use of misogynist language and symbols, and through practices such as harassing, belittling, and refusing to train racialized men and women. Interrogating the complex ways in which reinforced masculinity benefits men at the job site helps explain the minimal integration of women in the sector, as do studies that show the complex ways in which women negotiate their gender and sexual presentation so as to minimize harassment. ${ }^{30}$ Challenging sexist and racist practices is hindered by the fragmented character of the trades, however, and by the reliance on informal networks and relationships for training and employment. These challenges may explain why so few women have entered the trades relative to other male-dominated forms of employment, such as mining or auto manufacturing. ${ }^{31}$

For Jobs and Freedom: Race and Labor in America since 1865 (Lexington: University Press of Kentucky, 2007).

28. Herbert A. Applebaum, Royal Blue: The Culture of Construction Workers (New York: Holt, Rinehart \& Winston, 1981); Susan Eisenberg, We'll Call You If We Need You: Experiences of Women Working Construction (Ithaca: Cornell University Press, 1998).

29. Paap, Working Construction; David Roediger, The Wages of Whiteness: Race and the Making of the American Working Class, rev. ed. (New York: Verso, 2007).

30. Amy M. Denissen \& Abigail Saguy, "Gendered Homophobia and the Contradictions of Workplace Discrimination for Women in the Building Trades," Gender and Society 28, 3 (2014): 381-403.

31. Women's participation in the construction trades - unlike most other industries, in which women's participation grew rapidly after 1970 - has continued to hover at approximately 5 per cent. Status of Women Canada, "Fact Sheet: Economic Security" (Ottawa 2015). 


\section{Construction and Employment Programs}

THE ABOVE CHARACTERISTICS, both the temporal and spatial fragmentation of work and the exclusion of women and racialized workers from the skilled trades, have rendered construction an attractive site for job-creation strategies. Perhaps more than any other, construction is often viewed as a sector that can provide work for those who are unemployed, not participating in the labour market, living in poverty, or otherwise deemed "hard to employ" whether youth, women, Indigenous people, or immigrants. However, although targeted training and employment programs in the trades have been run by governments, nonprofits, and community groups for over 40 years, there are relatively few success stories.

A key attribute of construction that makes it attractive to governments and NGOs is its ability to grow in a short period of time. There is little lag time in construction, and the fragmented production process and prevalence of subcontracting allow for both old and new firms to expand rather quickly to absorb latent segments of the labour force. This characteristic has also made the sector attractive to all levels of government seeking to stimulate job growth. Governments have long looked to infrastructural-investment job-creation strategies because they at once renew infrastructure and provide employment. For example, Alberta's 2016 budget allocated $\$ 34.8$ billion in infrastructure spending as part of its Job Plan to mitigate job losses from the declining oil and gas sector. ${ }^{32}$ Additionally, unlike other blue-collar sectors, which have been declining over the past half century, construction employment tends to follow patterns of economic growth. Because the product of labour is spatially fixed and the work itself requires constant troubleshooting, construction employment is more immune to offshoring and technical displacement than are other goods-producing sectors. ${ }^{33}$ From 2001 to 2016, the proportion of the workforce employed in construction increased from 5.5 to 7.7 per cent, while the share of employment in manufacturing declined from 15.2 to 9.4 per cent over the same period. ${ }^{34}$

Construction is also attractive as a path to poverty alleviation for two reasons. First, both the diversity of skill levels required on a construction site and the apprenticeship training model lessen formal barriers to entry. Participants can begin working in the sector with minimal education and training, gaining skills while earning a wage as an apprentice. The ability to work while training makes construction a viable option for those living in poverty. In theory, the skills gained through programs can be leveraged for

32. Government of Alberta, Budget 2016: The Alberta Jobs Plan - Fiscal Plan 2016-19 (Edmonton, 14 April 2016), http://finance.alberta.ca/publications/budget/budget2016/fiscalplan-complete.pdf.

33. Erlich \& Grabelsky, "Standing at a Crossroads."

34. Statistics Canada, “Table 282-0007." 
future employment opportunities. Precisely because of the exclusivity of the skilled trades described above, states, provinces, municipalities, Indigenous governments, and nonprofits have invested in facilitating the entry of women, Indigenous people, immigrants, and racialized men into employment programs. Jobs in construction, and particularly the skilled trades, continue to be seen as high paying, giving those otherwise excluded from the trades the ability to move into more highly paid occupations. The idea that women with relatively little education can move out of poverty by entering a job normally typified as "male" has underpinned many women-in-trades programs. ${ }^{35}$

In urban areas, particularly in the United States, infrastructure projects have often been used as employment programs to provide members of racialized communities and/or those living in poverty with access to training and jobs. Nonprofits, citizen groups, and municipal governments have tied targeted employment programs into state welfare or infrastructure projects. Some examples examined by scholars include a transitional housing project in Toronto, ${ }^{36}$ a green retrofitting project in New Jersey, ${ }^{37}$ the building of a highway on Vancouver Island, and as discussed by James Nugent in this issue, an urban transit project in Toronto. These programs were initiated by different levels of government, often with the involvement of nonprofits, unions, and community groups. In Canada, countless employment programs have targeted Indigenous people for jobs in construction and training in the skilled trades, despite their overrepresentation in the sector as a whole. ${ }^{38}$ More recently, employment programs associated with construction of resource development projects are the result of community benefits agreements (СвAs) between Indigenous governments and resource companies. ${ }^{39}$ These employment programs are typically restricted to First Nations, Métis, or Inuit members of the communities affected by the development.

At first glance, these employment programs appear to be a win-win. The benefits of using infrastructure spending or resource development projects to provide jobs and training to groups who face relatively high unemployment,

35. Margaret Little, If I Had a Hammer: Retraining That Really Works (Vancouver: UBC Press, 2005).

36. Rae Bridgman, "I Helped Build That: A Demonstration Employment Training Program for Homeless Youth in Toronto, Canada," American Anthropologist 103, 3 (2001): 779-795.

37. Janice Fine, "When the Rubber Hits the High Road: Labor and Community Complexities in the Greening of the Garden State," Labour Studies Journal 36, 1 (2011): 122-161.

38. Little, If I Had a Hammer; Marjorie Griffin Cohen \& Kate Braid, "Training and Equity Initiatives on the British Columbia Vancouver Island Highway Project: A Model for Large-Scale Construction Projects," Labour Studies Journal 25, 3 (2000): 70-103; Frances Abele, Gathering Strength (Calgary: Arctic Institute of North America, 1989).

39. Suzanne Mills \& Brendan Sweeney, "Employment Relations in the Neo-Staples Resource Economy: Impact Benefit Agreements and Aboriginal Governance in Canada's Nickel Mining Industry," Studies in Political Economy 91, 1 (2013): 7-34. 
are living in poverty, and/or are underrepresented in construction are selfevident. However, most of the available research charts a number of challenges resulting from the characteristics of the industry described above. First and foremost, the fast pace and fragmented labour process of large construction projects means that there are multiple employers and unions with which to contend. This decentralized organization creates enforcement challenges. Additionally, construction unions and contractors are often resistant to the inclusion of workers who are from diverse backgrounds and who are not union members. As well, even when projects have been successful in increasing the numbers of workers hired, the new workers and apprentices are typically clustered in lower-skilled occupations and trades, often working as labourers, as truck drivers, or in carpentry. ${ }^{40}$ Finally, because working in construction requires movement from job to job, those who gain experience on a project as part of an equity initiative are likely to face barriers to continued work in the industry once the project-specific program has ended. In short, although scholars studying employment programs have documented some success, these programs have largely been limited by the highly fragmented organization of the industry, the tight-knit informal relationships among contractors and unions, and the perpetual gender and racial bias in the concept of the skilled worker. These challenges are deepened by the neoliberalization of formerly public infrastructure projects, as Nugent describes below.

\section{New Directions for Labour Studies}

THE ARTICLES IN THIS SECTION help to reshape scholarship about construction work by developing the above themes, among others. Each contribution provides a distinct viewpoint into how the industry is organized and how it is experienced by workers in a variety of geographic and employment contexts. Together, they challenge previous depictions of construction work as highquality employment represented by strong unions. They draw attention instead to some of the critical ways in which construction work today diverges from previous formulations, with challenges to job quality and workers' voices in the industry. For example, Foster and Barnetson analyze employment numbers to chart the use of temporary foreign workers by construction employers in Alberta. Tufts and Thomas draw attention to the rise of the accommodationist union CLAC and its use of populism to recruit members. Nugent charts the challenges that the neoliberalization of public projects poses to the ability of programs to successfully promote equity in construction.

Critically, two of the contributions draw connections between the limited success of attempts to diversify construction work and broader economic changes within the sector. Foster and Barnetson set out to evaluate the success of Alberta's ten-year plan to increase the participation of women, youth,

40. Cohen \& Braid, "Training and Equity Initiatives”; Abele, Gathering Strength. 
Indigenous peoples, and immigrants in construction. To accomplish this, they compare employment of temporary foreign workers with that of women, Indigenous peoples, and immigrant workers from 2003 to 2013, a period that saw dramatic fluctuations in provincial labour demand as oil prices rose and fell. Their analysis suggests that underrepresented groups are participating in a secondary labour market that is more volatile than the one experienced by white men. Their findings, however, also demonstrate how the employment of underrepresented groups was overshadowed by much larger fluctuations in the numbers of temporary foreign workers. Foster and Barnetson suggest that this dramatic volatility points to employer preferences for temporary foreign workers over other marginalized groups during periods of temporary labour shortages. This article offers empirical evidence of persistent employer preferences for white men and for the use of temporary foreign workers as a hyperflexible supply of labour.

Nugent's insightful article contributes to the literature on construction employment programs through a case study of employment provisions in a $\mathrm{CBA}$ for the construction of a light rail transit line in Toronto. The case highlights some of the challenges of implementing and enforcing community-based agreements in construction. In particular, Nugent's article highlights some of the challenges to successful СBAs and their capacity to increase access to training for construction trades by groups historically excluded from higherskilled work in construction. The case study provides an important example of how new forms of governance can provide illusory community participation and change while reinforcing status quo hiring provisions. In particular, the inability of community activists to obtain binding criteria in their requests for proposals and subcontractor contracts limited the success of the program. The article also highlights how community groups need to guard against the co-optation of their efforts to democratize development by governments with neoliberal development agendas.

The focus by Tufts and Thomas on CLAC as a class-collaborationist union fills a lacuna in the construction literature. Most labour studies scholarship has focused on traditional ВСтUs and neglected the rise in unions such as CLAC. Moreover, understanding the use of populist rhetoric in labour and employer campaigns is critical, given its increasing prevalence and success in political campaigns. Adopting a spatial framework for their analysis, Tufts and Thomas argue that CLAC has targeted construction because the fragmented nature of the sector and the small size of its employers provide room that allows a union like CLAC to move in. They also demonstrate how CLAC undermines the strategic power of ВС TUs by undermining the scale of organizing that ВС ТUs have developed over generations. CLAC has used populist rhetoric to circumvent the link between union hall membership and union employment and to effectively rescale labour relations in construction using the notion of "freedom of association." 
These articles thus begin to develop an appreciation of the complexity of the contemporary construction sector by connecting labour market fluctuations to temporal and spatial fragmentation and to worker diversity, indicating that more research is critically needed. Construction is one of the most prevalent forms of employment in Canada, yet labour scholars have a relatively poor understanding of relations within the sector and of its dynamics. The drastic changes occurring in construction, including the weakening strength of traditional unions, the rising dominance of non-unionized work and classcollaborationist unions, and the degradation of working conditions alongside the increased use of foreign workers, are occurring in other sectors as well. Moreover, it is critical that we understand how the maintenance of racialized job hierarchies and the exclusion of women are connected to labour relations and economic conditions in the sector. These connections, which are highly pronounced in construction, will likely become more common in other sectors with the rise of precarious employment and a shift toward greater informality. In short, bringing construction to the centre of our analysis is vital - not only to better understand the work in a dominant sector, but also to better understand the changing world of work in Canada as a whole. 


\section{CONTRIBUTORS / COLLABORATEURS}

Bob Barnetson is professor of labour relations at Athabasca University. His research focuses on the political economy of workplace injury, farm workers, and migrant workers. He is the coauthor (with Jason Foster) of Health and Safety in Canadian Workplaces (Athabasca University Press, 2016).

Michael Dennis teaches at Acadia University. His most recent publication, "The Idea of Full Employment: A Challenge to Capitalism in the New Deal Era," appeared in Labor: Studies in Working-Class History.

Thierry Drapeau is a contract faculty member in the Department of Industrial Relations at Université du Québec en Outaouais. His research explores the early modern development of working-class internationalism in the Atlantic world.

Jason Foster is assistant professor of human resources and labour relations at Athabasca University. He is the author of Defying Expectations: The Case of UFCW 401 (Athabasca University Press, 2017) and coauthor (with Bob Barnetson) of Health and Safety in Canadian Workplaces (Athabasca University Press, 2016). His research interests include migrant workers, occupational health and safety, and union renewal.

Spencer Hamelin completed his Bachelor of Arts (Honours) and Master of Arts degrees in history at the University of Guelph. His MA focused on Canadian unions and the North American Free Trade Agreement.

Suzanne E. Mills is an associate professor in Labour Studies and Geography and Earth Sciences at McMaster University. Her research has focused on gender, Indigeneity and work in construction and resource industries in Canada's provincial and territorial Norths and on trade union engagement with equity and diversity initiatives.

\begin{abstract}
James Nugent is a PhD candidate in the Department of Geography and Planning at the University of Toronto. His research and activism focus on labour-community coalitions, employment equity, and urban political ecology.
\end{abstract}

Jacques Rouillard, professeur émérite au Département d'histoire de l'Université de Montréal, est l'auteur de plusieurs articles sur l'histoire des travailleurs québécois. Il a publié plusieurs ouvrages sur le syndicalisme, dont Le Syndicalisme québécois. Deux siècles d'histoire (2004) et L'expérience syndicale au Québec. Ses rapports avec l'État, la nation et l'opinion publique (2008). Il fera paraître prochainement un volume sur l'histoire du Conseil des métiers et du travail de Montréal de 1897 à 1930, organisme à la source de la social-démocratie au Québec.

Nick Ruhloff-Queiruga is a JD candidate at Osgoode Hall Law School and holds an MA in Work and Society from McMaster University's School of Labour Studies.

Larry Savage is chair of the Department of Labour Studies at Brock University.

Mark Thomas is director of the Global Labour Research Centre and associate professor in the Department of Sociology, York University.

Brian Thorn teaches English and History at Nipissing University. He is the author of From Left to Right: Maternalism and Women's Political Activism in Postwar Canada (U BC Press, 2016).

Steven Tufts is associate professor in the Department of Geography, York University.

Tyler Wentzell is a lawyer practicing in dispute resolution in Toronto. He is interested in the history and modern phenomenon of foreign enlistment. 
Reproduced with permission of copyright owner. Further reproduction prohibited without permission. 